\title{
UNDERSTANDING THE NATURE OF THE MAIN CHARACTER IN RUSSIAN LITERATURE ON THE MATERIAL OF THE NOVEL "A HERO OF OUR TIME" BY M.Y. LERMONTOV
}

\author{
COMPREENDENDO A NATUREZA DA PERSONAGEM PRINCIPAL DA \\ LITERATURA RUSSA NO MATERIAL DO ROMANCE "UM HERÓI DO NOSSO \\ TEMPO" DE M.Y. LERMONTOV
}

\author{
ENTENDIENDO LA NATURALEZA DEL PERSONAJE PRINCIPAL DE LA \\ LITERATURA RUSA SOBRE EL MATERIAL DE LA NOVELA "UN HÉROE DE \\ NUESTRO TIEMPO" DE M.Y. LERMONTOV
}

\author{
Svetlana M. PETROVA ${ }^{1}$
}

\begin{abstract}
The relevance of the study is conditioned by the necessity to popularize the Russian language in classes with a foreign audience by referring to Russian classical literature (on the example of the novel "A Hero of Our Time" by M.Y. Lermontov) with the use of innovational education technology of graphic and symbolic analysis of fiction. The purpose of the study is to create a system of lessons on the analysis of the novel "A Hero of Our Time" by M. Y. Lermontov, for teaching the Russian language to a foreign audience with the application of modern technologies of teaching Russian literature to foreigners, using innovational teaching forms such as graphic symbols and key concepts reflecting the history, philosophy, traditions, and customs of the first quarter of the 19th century. The main method of study used for this problem is a creation of a graphic and symbolic system of analysis for the novel "A Hero of Our Time" by M.Y. Lermontov during Russian language classes for foreign students, which would allow viewing this problem as an innovational method of teaching the Russian language to foreigners on the material of fiction. The paper presents a system of graphic and symbolic analysis of the work of fiction, demonstrates the features of its application, develops an algorithm for the implementation of this system into teaching Russian to foreigners. The proposed system of graphic and symbolic analysis of a work of fiction in the context of teaching Russian to foreigners is an effective form of mastering the educational material for students which contributes to their realization of the communicative and linguoculturological competencies.
\end{abstract}

KEYWORDS: Russian as a foreign language. Graphic and symbolic analysis. M.Y. Lermontov.

RESUMO: A relevância do estudo está condicionada pela necessidade de popularizar a língua russa nas aulas com um público estrangeiro, referindo-se à literatura clássica russa (a exemplo do romance "Um herói do nosso tempo", de M. Y. Lermontov) com o uso de tecnologias educacionais inovadoras de análise gráfica e simbólica da ficção. O objetivo do estudo é criar um sistema de aulas sobre a análise do romance "Um Herói do Nosso Tempo"

${ }^{1}$ M.K. Ammosov North-Eastern Federal University (NEFU), Yakutsk - Russia. Professor and Head of the Department of Russian as a Foreign Language. Doctor of Pedagogic Sciences. ORCID: https://orcid.org/00000001-5191-0942.E-mail: metlit@mail.ru 
de M. Y. Lermontov para ensinar a língua russa a um público estrangeiro com a aplicação de tecnologias modernas de ensino de literatura russa, usando formas de ensino inovadoras, como símbolos gráficos e conceitos-chave que refletem a história, filosofia, tradições e costumes do primeiro trimestre do século 19. O principal método de estudo utilizado para este problema é a criação de um sistema gráfico e simbólico de análise para o romance "Um Herói do Nosso Tempo" de M. Y. Lermontov durante as aulas de língua russa para alunos estrangeiros que permitiriam ver este problema como um método inovador de ensino da língua russa para estrangeiros no material de ficção. $O$ artigo apresenta um sistema de análise gráfica e simbólica da obra de ficção, demonstra as características de sua aplicação, desenvolve um algoritmo para a implementação deste sistema no ensino de russo para estrangeiros. O sistema proposto de análise gráfica e simbólica de uma obra de ficção no contexto do ensino de russo para estrangeiros é uma forma eficaz de dominar o material educacional para os alunos, o que contribui para a realização das competências comunicativas e linguoculturológicas.

PALAVRAS-CHAVE: Russo como língua estrangeira. Análise gráfica e simbólica. M.Y. Lermontov.

RESUMEN: La relevancia del estudio: La relevancia del estudio está condicionada por la necesidad de popularizar el idioma ruso en clases con público extranjero haciendo referencia a la literatura clásica rusa (en el ejemplo de la novela "Un héroe de nuestro tiempo" de MY Lermontov) con el uso de tecnología educativa innovadora de análisis gráfico y simbólico de la ficción. El propósito del estudio es crear un sistema de lecciones sobre el análisis de la novela "Un héroe de nuestro tiempo" de M.Y. Lermontov por enseñar el idioma ruso a una audiencia extranjera con la aplicación de tecnologías modernas de enseñanza de literatura rusa a extranjeros, utilizando formas de enseñanza innovadoras como símbolos gráficos y conceptos clave que reflejan la historia, filosofia, tradiciones y costumbres del primer trimestre de la Siglo 19. Métodos: El principal método de estudio utilizado para este problema es la creación de un sistema de análisis gráfico y simbólico para la novela "Un héroe de nuestro tiempo" de M.Y. Lermontov durante las clases de lengua rusa para estudiantes extranjeros que permitirían ver este problema como un método innovador de enseñar la lengua rusa a extranjeros sobre el material de ficción. Resultados: El trabajo presenta un sistema de análisis gráfico y simbólico de la obra de ficción, demuestra las características de su aplicación, desarrolla un algoritmo para la implementación de este sistema en la enseñanza del ruso a extranjeros. Importancia práctica: El sistema propuesto de análisis gráfico y simbólico de una obra de ficción en el contexto de la enseñanza del ruso a extranjeros es una forma eficaz de dominar el material educativo para los estudiantes que contribuye a la realización de las competencias comunicativas y lingüisticas.

PALABRAS CLAVE: Ruso como lengua extranjera. Análisis gráfico y simbólico. M.Y. Lermontov.

\section{Introduction}

The promotion of the Russian language is one of the strategically important areas of the modern international policy of the Russian Federation (RUSSIA, 2016). Today we witness 
a qualitative change in the ethnolinguistic worldview (KORNILOV, 2011). Language is not just a means of communication (AKOPYANTS, 2019), and, therefore, we must pay serious attention to a balanced language policy capable of maintaining the interest of the Russian language and culture at a sufficiently high level in all countries. The most important objective of the modern language policy is to preserve the richest traditions of the authentic Russian culture. In the era of digitalization, modern society is trying to find an optimal balance in using the potential of educational resources hosted on various online platforms. With a wellplanned approach to the current language situation, education in Russian can become an excellent way of integrating the individual into the global world (SCHUKIN, 2010).

The modern socio-economic policy of the Republic of Sakha (Yakutia), the expansion of the information space, and the creation of new information sources have led to the need for scientific understanding of the situation and looking for practical solutions demanded by it. There is a need for an in-depth study of the ethnolinguistic aspect of the methods of teaching Russian as a foreign language (RFL) for the implementation of intercultural communication. In the course of studies, foreign students acquire general cultural and professional competencies. The process of teaching RFL is directly affected by the features of the language environment of the university and the region of study. The practice has shown that teaching Russian to foreigners at the present stage must correspond to the new geopolitical, global socio-linguistic situation.

The creation of the project "Implementation of the functioning model for open education centers teaching in Russian and teaching the Russian language based on interest clubs for professional and specialized communities" and of the Russian-Chinese club "Almaz" for communication in Russian was conditioned by external factors related to the interest of the Asia-Pacific region (APR) (the People's Republic of China (PRC)) to the North-East of Russia, in particular, in the Republic of Sakha (Yakutia) as a region with a high level of natural resource economic potential, as well as internal factors such as the presence of a Department of RFL at the North-East Federal University (NEFU), which is a promising area of research, actively implementing the practice of teaching Russian as foreign modern innovative techniques.

These methods and practices were tested at international conferences ("Russian Studies in the North-East of Russia and the APR countries", 2014, 2017), Forums "Russian Studies in Russia and China: innovative practices" $(2018,2019)$ with the participation of Russian language teachers from the APR countries (China, Korea, Mongolia, Vietnam, Japan). As a result of these events, a strategy for further cooperation with Russian teachers 
from the APR was developed, which served as an impetus for the creation of the project. Based on the research of modern Russian scholars, the linguistic culture of the region can be represented as an unbroken chain of linguistic and cultural situations (LCS), including materials of classical works of fiction, as well as the implementation of communicative and socio-cultural competencies that motivate the study of RFL. The project developers offer a comprehensive technology for designing the educational environment that accompanies teaching RFL at the NEFU, based on the scientific foundations laid down by ethnolinguistic principles. In the period from 2018 to 2020, some electronic educational resources (EERs) in RFL were put into practice for various groups studying in China: Heilongjiang Oriental University, Changchun Institute of Science and Technology, Boda Institute of Jilin Pedagogical University. Experimental groups were organized with testing of innovative practices under the leadership of the Department of RFL at the NEFU.

The Republic of Sakha (Yakutia), as the largest region in the north-east of the Russian Federation, has also become the subject of interest from its closest foreign neighbors. Assessing the educational trends in Southeast Asia in the field of training teachers of RFL and the process of teaching students RFL, such as the insufficient number of hours in the curriculum, limited language practice, the lack of modern educational and methodological complexes, the lack of Russian-language educational information environment, the Faculty of Philology and the Department of RFL of the NEFU initiated the project "Russian-Chinese club "Almaz" for communication in Russian". The project includes the development and implementation of a system of measures aimed at the formation of the Russian educational environment with ethnocultural component, and the application of new research technologies and methods of teaching, contributing to the dialogue of cultures. The social and public significance of the project is to promote the Russian language for foreign students, as well as create an open educational environment, conducive to the development of interest of foreigners to study the Russian language, literature, culture, history of Russia, in improving the scientific and methodical base of teaching RFL. The scientific and pedagogical significance of the project is to create innovative educational start-ups based on different operating systems, to use ethnically oriented technologies, methods, forms, techniques of teaching RLF, taking into account the regional features of the Republic of Sakha (Yakutia).

The implementation of the principle of cultural conformity in modern education is becoming increasingly important, and this is impossible without familiarizing students with a huge layer of graphic culture, which will contribute to the mastery of verbal and non-verbal means of communication. 
The researchers rightly point out the need for serious development of the theory and practice of using graphics in the educational process (Bespalko, Gomoyunov). To solve this problem, we need ideas based on the latest achievements in the field of psycholinguistics, linguistic-cultural studies, literary studies (LIPICH, 2005), and philosophy. Innovative technologies that can radically change the established system of knowledge acquisition are becoming a reflection of the new strategy of teaching and learning. Modern humanitarian thinking is characterized by increased attention to the role of language in the formation of the cultural and semiotic component of public consciousness and intercultural social interaction.

Attention of scientists is increasingly attracted to semiotics, an interdisciplinary science. Semiotic ideas were already laid down in ancient philosophy. The founders of semiotics asserted that "all human reasoning uses certain signs or characters" (G. W. Leibniz) and that "all this universe is perfused with signs if it is not composed exclusively of signs" (C. S. Peirce). In the 20th century, the traditions of Russian semiotics go back to the works of J. Baudouin de Courtenay, A. A. Potebnya, A. A. Fortunatov. A. F. Losev defined the symbol as an "expanded sign". This idea was continued by other researchers who believed that "a sign expresses, and a symbol reveals a given meaning" (E.V. Ilyenkov, M.I. Makarov, M.K. Mamardashvili, A.M. Pyatigorsky).

Semiotics as a "method of dealing with signs" (M.K. Mamardashvili) represents a new direction in the science of signs in the modern education system and has been developed and implemented in educational institutions of the region (PETROVA, 2020).

The method of teaching RFL has a long history and its professional representatives at different stages of the development of this science (O.D Mitrofanova, E.I. Motina, E.M. Vereshchagin, V.G. Kostomarov, M.I. Vyatutnev, E. I. Passov, S.A. Khavronina, V.G. Moskovkin, etc.) (VISHNYAKOV, 2013). At the same time, RFL as a pedagogical science is constantly being improved, following the times (Lysakova, 2016).

\section{Materials and Methods}

\section{Methods of the study}

The method used for this study was the system of teaching RFL using graphic and symbolic analysis based on the novel "A Hero of Our Time" by M.Y. Lermontov. 


\section{Experimental base of the study}

The experimental base of the study is the Federal State Autonomous Educational Institution of Higher Education "NEFU named after M.K. Ammosov".

\section{Stages of the study}

The study was performed in three stages:

1. At the first stage, a theoretical analysis of methodological approaches in the special literature on philosophy, psychology, linguistics, pedagogy, methodology was carried out; problems, goals, research methods were formulated, and an experimental research plan was drawn up.

2. At the second stage, we developed an innovative system of graphical and symbolic analysis of the novel "A Hero of Our Time" by M.Y. Lermontov in the context of teaching the Russian language to a foreign audience; modern teaching technologies were identified and substantiated; experimental work was carried out; the conclusions obtained during the experimental work were analyzed and clarified.

3. At the third stage, the experimental work was completed, the theoretical and practical conclusions were clarified, the results obtained were generalized and systematized.

\section{Results}

\section{Structure and content of the model}

We chose the novel "A Hero of Our Time" by M.Y. Lermontov due to the interest of foreign students in Russian classical literature, the desire to understand "the soul of the Russian people" on the works of Russian literature of the 19th century (RANDZHANA, 2019, p. 198). In this respect, the novel "A Hero of Our Time" by M.Y. Lermontov is suitable as it most clearly reflects the features of the main character of Russian literature not only of the Lermontov era but also of later times (CHEKALIN, 1991). In the Preface to the novel, the author explains to the reader the correct understanding of his character. According to the author, Pechorin "affords the author an opportunity of explaining the object of the work, or of vindicating himself and replying to his critics." Much of this preface is explained by the author himself. "The Hero of Our Time.. is, in fact, a portrait, but not of one man only: he is a composite portrait, made up of all the vices which flourish, full-grown, amongst the present generation. 
The composition of the novel is a mystery, revealing the nature of Pechorin, the psychology of the main character. The varied composition of the novel reflects a split of the character's fate. The novel has not yet been read, but many things are already clear. Numerous monologues of Pechorin in different chapters of the novel complement his characterization.

The graphics used in the chapters of the novel clearly show how the nature of the character manifests itself in different life situations.

Table 1 - Chapters

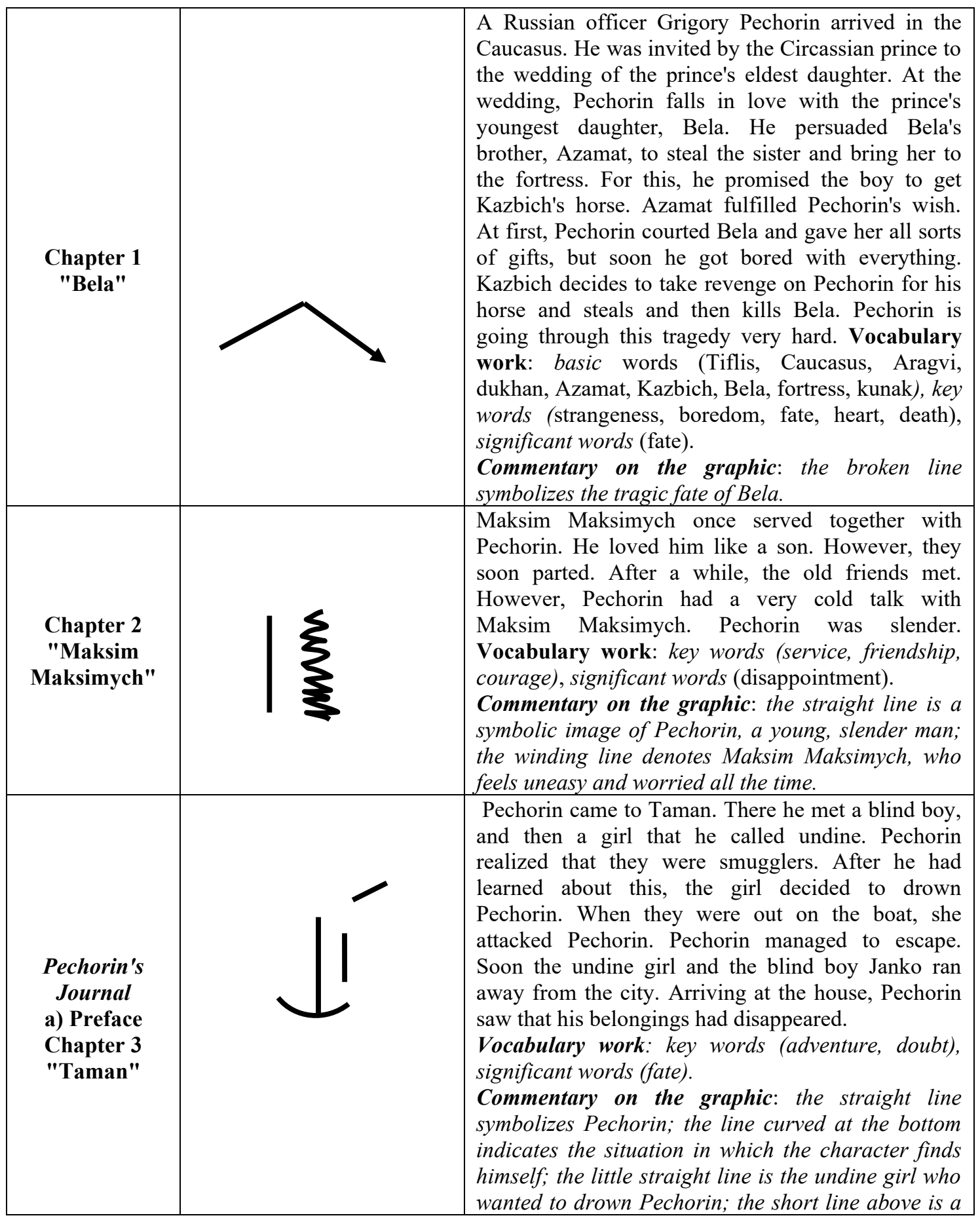




\begin{tabular}{|c|l|}
\hline Chapter 4 \\
"Princess \\
Mary" \\
test of the fate of Pechorin. \\
Pechorin comest to Pyatigorsk for treatment. Here he \\
meets the cadet Grushnitsy. Grushnitsky is in love \\
with Princess Mary. Princess Mary, in turn, falls in \\
love with Pechorin. However, Pechorin is in love \\
with another woman, Vera. Grushnitsky starts \\
gossiping about Pechorin. Pechorin challenges \\
Grushnitsy to a duel. At the duel, Pechorin kills \\
Grushnitsky \\
Vocabulary work: key words (challenge, reason, \\
envy, friendship, passion, evil, good), significant \\
words (passion). \\
Commentary on the graphic: the winding spot is a \\
symbolic designation of the "spa society" in \\
Pyatigorsk, where Pechorin comes to be treated; the \\
crossing lines indicate Pechorin's protest against \\
this society.
\end{tabular}

Source: Prepared by the author

The table shows that each chapter of the novel not only has its graphic display due to the content of the text but also reflects certain trends inherent in the character of the protagonist. This also applies to significant words that are not accidentally repeated in each chapter (death, fate). Of great importance in understanding the events taking place are those additions that the teacher includes in the work on the analysis of this novel.

\section{Supplement to Chapter 1 "Bela"}

For the first time we learn about Pechorin from the words of Maksim Maksimych, who noted some peculiarity in him: "He was a splendid fellow, I can assure you, but a little peculiar... Yes, sir, a very eccentric man; and he must have been wealthy too. What a lot of expensive trinkets he had!.." We learn even more about the character from himself: 
Mine is an unfortunate disposition; whether it is the result of my upbringing or whether it is innate-I know not. I only know this, that if I am the cause of unhappiness in others I myself am no less unhappy ... In my early youth...I began madly to enjoy all the pleasures ...and, of course, such pleasures became irksome to me. Then I launched out into the world of fashion - and that, too, soon palled upon me. I fell in love with fashionable beauties and was loved by them, but my heart remained empty ... I began to read, to study — but sciences also became utterly wearisome to me ... When I saw Bela..., I, fool that I was, thought that she was an angel sent to me by sympathetic fate... Again I was mistaken. The love of a savage is little better than that of your lady of quality, the barbaric ignorance and simplicity of the one weary you as much as the coquetry of the other. I would give my life for her-only I am bored with her... I am also most deserving of pity-perhaps more than she. My soul has been spoiled by the world, my imagination is unquiet, my heart insatiate. To me, everything is of little moment. ... and my life grows emptier day by day. One expedient only is left to me-travel (LERMONTOV, 1998, p. 41, our emphasis).

After the death of Bela Pechorin was ill for a long time, and grew thin...

At the end of each chapter, questions are formulated to identify the understanding of the text by foreign students

1. How do you assess Pechorin's behavior?

2. What do you see as the cause of Bela's death? What is your attitude to the girl?

\section{Supplement to Chapter 2 "Maksim Maksimych"}

Here is a portrait of Pechorin:

He was of medium height. His shapely, slim figure and broad shoulders gave evidence of a strong constitution... linen of dazzling whiteness, ...his small, aristocratic hand"... "Notwithstanding the light colour of his hair, his moustaches and eyebrows were black - a sign of breeding in a man... he had a slightly turned-up nose, teeth of dazzling whiteness, and brown eyes-I must say a few words more about his eyes."From my first glance at his face, I should not have supposed his age to be more than twentythree, though afterwards I should have put it down as thirty. His smile had something of a child-like quality (LERMONTOV, 1998, our emphasis).

In the description of the character's eyes:

In the first place, they never laughed when he laughed. Have you not happened, yourself, to notice the same peculiarity in certain people?... It is a sign either of an evil disposition or of deep and constant grief. ... blinding but cold. His glance-brief, but piercing and heavy-left the unpleasant impression of an indiscreet question and might have seemed insolent had it not been so unconcernedly tranquil (LERMONTOV, 1998, our emphasis). 
Deep psychologism in creating the image of the character was reflected in a small scene where, when asked by Maksim Maksimych about Bela, "Pechorin turned just the slightest bit pale and averted his head". "Yes, I remember!" he said, almost immediately forcing a yawn".

1. What new things have you learned about Pechorin?

2. How do you explain Pechorin's behavior?

\section{Supplement to Chapter 3 "Taman" (Pechorin's Journal)}

\section{Supplement to Chapter 4 "Princess Mary"}

On reading over these notes, I have become convinced of the sincerity of the man who has so unsparingly exposed to view his own weaknesses and vices. The history of a man's soul, even the pettiest soul, is hardly less interesting and useful than the history of a whole people; especially when the former is the result of the observations of a mature mind upon itself and has been written without any egoistical desire of arousing sympathy or astonishment (LERMONTOV, 1998, our emphasis).

Pechorin about himself: I have an innate passion for contradiction - my whole life has been nothing but a series of melancholy and vain contradictions of heart or reason.

The new character of the novel Doctor Werner, with whom Pechorin soon became a friend: "I, for my part, am ill-adapted for friendship".

Pechorin about himself: "why have I lived? For what purpose was I born?.. mine was an exalted destiny because I feel that within my soul are powers immeasurable... To none has my love brought happiness, because ... for myself alone I have loved..."

1. Why did Pechorin challenge Grushnitsky to a duel?

2. How is Pechorin's character revealed?

\section{Supplement to Chapter 5 "The Fatalist"}

The chapter "Fatalist" occupies a key place in the novel because it reflects the worldview of the hero and the writer, their views on the philosophy of life, on the values of human existence. "In my early youth, I was a dreamer... And what is there left to me of all these? ... it has become wearisome and nauseous to me... I prefer to doubt everything."

The composition of the novel requires a special conversation, as it breaks the chronology of the events taking place: this was also a certain intention of the writer. If we 
bear in mind the chronology of events in the novel, i.e. the storyline, then it should look like this:

1. "Taman" -Pechorin's adventure with the "Undine";

2. "Princess Mary", which tells the story of Mary with Grushnitsky and the duel of the main characters;

3. "Fatalist" - the episode with Vulich;

4. "Bela" - the abduction of Bela and the journey of the wandering officer (narrator) with Maksim Maksimych;

5. "Maksim Maksimych"- a meeting with this character in Vladikavkaz;

6. "Preface to" Pechorin's Journal" -the news of the death of the main character.

However, the chronology of the novel is broken, and we read M.Y. Lermontov's novel in the following sequence:

\section{1. "Bela";}

2. "Maksim Maksimych";

3. "Preface to" Pechorin's Journal";

4. "Taman";

5. "Princess Mary";

6. "The Fatalist".

Questions on identifying the understanding of the content of the chapter

1. How is Pechorin's character revealed in this chapter?

2. What is fate? How is this problem solved in the chapter?

\section{The ascertaining stage}

The search for effective forms of teaching the Russian language to an international audience, reflected in the works of famous scholars and methodologists (V.G. Moskovkin, S.A. Khavronina, V.M. Shaklein, I.P. Lysakova, etc.), led us to thoughts on the importance of including material on Russian literature in the system of teaching RFL (KULIBINA, 2001). The text of fiction reflects the correct grammatical structure of the Russian language (CHEKALIN, 1991). Foreigners learn to "see" the text, which contributes to the development 
of their figurative, associative thinking, improve oral coherent speech, expand their vocabulary, deepen their understanding of the lexical richness of the Russian language. The system of analysis of a work of fiction developed by us using practice-oriented traditions of semiotics in the classroom in the Russian language helps foreign students to master the studied language faster and more effectively and better understand the work being studied.

\section{Formative stage}

We chose the novel "A Hero of Our Time" by M.Y. Lermontov which attracts the attention of foreign students not only by its name but also by the problems that concern young people in our time (BROZDELI, 2015).

The adapted texts of the chapters of the novel with the obligatory stress marks (which is very important at all stages of teaching the Russian language) serve as educational material for foreigners. In each adapted text presented, attention is paid to vocabulary work, in particular, to key words and significant words. Work in this direction is carried out at all stages of the lesson.

The analysis of the adapted texts of the chapters of the novel is preceded by pre-text work related to the historical and literary commentary, the use of various means of modern teaching technologies, which in many respects enlivens the learning process. This is also due to an acquaintance with the language of the work, in which there are many monologues, reservations, dots, features of the portrait characteristics of the main character (MATVEEV, 2019).

The main goal at this stage of teaching Russian to foreigners is to arouse interest in the Russian word, in literature, to develop a culture of reading, speaking, retelling. In the course of the work, attention is drawn to the features of the composition of the novel, as a reflection of the inner contradiction of the author himself: the events in the novel do not take place as they actually did, but as the author himself intended. The author's preface to the novel presents a great difficulty for students. We comment on this episode, which helps foreigners to understand the educational material better and more deeply. We also pay attention to the national flavor of the novel (the Caucasus, Circassian prince, fortress, dukhan, revenge, mountaineer Kazbich, Pyatigorsk, etc.). 


\section{Control stage}

The study has shown that reading Russian literature in Russian language classes for foreign students greatly contributes to the development of interest in the history and culture of Russia, develops their cognitive, analytical, and research activities. In the process of analyzing the studied work, students receive the necessary knowledge that contributes to the understanding of the culture of another nation. The use of graphic and symbolic analysis of the novel "A Hero of Our Time" by M.Y. Lermontov not only contributes to its understanding to the greatest extent but also activates the vocabulary of students and strengthens their desire to speak Russian.

\section{Discussion}

Researchers note that the work of M.Y. Lermontov has -a special type of romantic attitude. Lermontov's romanticism belongs to late romanticism, which revised early romanticism, the romanticism of the Pushkin era, full of optimism and life-affirmation. Lermontov's work became a vivid expression of late romanticism, rebellious, tinged with deep tragedy. The peculiarity of Lermontov's romanticism - is the romanticism of a new intensity, a new psychological quality, and inner discomfort, romanticism, in which the historically formed "under-embodiment", "under-realization" of the ideas of early Russian romanticism again becomes relevant and in-demand (GERASIMENKO, 2002). His work reflected the general tendency in the development of Russian literature, not "overcoming" of romanticism, but the possibility of its fullest artistic self-realization by subsequent and organic assimilation of romantic discoveries and conquests by the aesthetics of realism. The great critic and writer A.I. Herzen noted that "Lermontov's meditation is -his poetry, his torment. His strength." F.M. Dostoevsky clairvoyantly remarked on the power of influence of M.Y. Lermontov's creativity for subsequent generations: "If Lermontov had remained to live, we would have had a great poet [...] a true ' sympathizer of the people's grief'. However, this name went to Nekrasov."

The novel "A Hero of Our Time" by M.Y. Lermontov created in the troubled 18381840 s has been included in the literature program both of schools and universities. The statement given to the novel by V.G. Belinsky predetermined its fate: "A Hero of Our Time"is a sad thought about our time... ". In this regard, in the classroom, during an analytical conversation, using modern teaching technologies, we pay special attention to the historical 
aspect, which is important for foreign students to understand the moral and ideological position of the writer (ZHURAVLEVA, 2018). To do this, we turn to different years of life, so that students better understand the features of the spiritual and mental state of the young poet, ranging from his youthful essay "I am the son of suffering" to mature poems like "I venture out alone along the road [...]", "No, I'm not Byron; I am, yet, another $[\ldots] "$.

Preparatory work is being carried out to analyze the adapted chapters of the novel "A Hero of Our Time" by Lermontov with the implementation of mandatory requirements for the work: affixed stress in the text, vocabulary work (highlighting key words and searching for significant words). Significant words (our proprietary method) reflect the idea of the work. In the course of an analytical conversation with students using additional commentary and additional explanatory work, these words are revealed (SMOL, 2015).

The most difficult stage of work is the teacher's explanation of the features of the composition of the novel and their free interpretation by the author of the novel. Corresponding work is carried out according to the table presented in the text.

\section{Conclusion}

Thus, from our experiment, we can conclude that the work on the analysis of a work of fiction in the context of teaching the Russian language to foreign students has shown its effectiveness, which affected the increased interest of students in the language of M.Y. Lermontov, the desire to learn more about the life of the writer, his work. Graphic and symbolic analysis of the novel "A Hero of Our Time" by M.Y. Lermontov contributed to the development of the students' analytical activity, creative thinking, enrichment of vocabulary, thanks to familiarity with the literary text.

Studying classical Russian literature by foreigners symbolizes their inner need to understand better the Russian language, history, culture, traditions, and customs of Russia.

ACKNOWLEDGMENTS: The paper was written within the framework of the Grant in the form of subsidies for the implementation of measures aimed at the full functioning and development of the Russian language, the departmental target program "Scientific, methodological and staffing support for teaching the Russian language and the languages of the peoples of the Russian Federation" of the subprogram "Improving the management of the education system" of the state program of the Russian Federation "Development of education". 
Lot 1.2 "Implementation of functioning models for open education centers teaching in Russian based on interest clubs among professional and specialized communities." November 24, 2020, No. 073-15-2020-2637.

\section{REFERENCES}

AKOPYANTS, A. M. Rol i mesto russkogo yazyka v epokhu globalizatsii: problemy, perspektivy, protivorechiya [The role and place of the Russian language in the era of globalization: problems, prospects, contradictions]. In: AKOPYAN, K. S. (Ed.). Russkii yazyk na perekrestke epokh: traditsii i innovatsii v rusistike. Sbornik nauch. st. po materialam IV Mezhdunarodnoi nauchno-prakticheskoi konferentsii. Yerevan: Russian-Armenian (Slavonic) University, 2019. p. 11-15.

BROZDELI, A. O. Tekst kak lingvostranovedcheskii resurs obucheniya rechevomu obshcheniyu $\mathrm{v}$ prepodavanii russkogo yazyka kak inostrannogo [Text as a linguistic and cultural resource for teaching speech communication in Russian as a foreign language]. In: Universitetskie chteniya - 2015, 13-14 yanvarya. Metodicheskie materialy PGLU [University Readings 2015, Jan. 13-14. Methodical materials of Pyatigorsk State Linguistic University (PGLU)]. Pyatigorsk: Izd-vo PGLU, 2015.

CHEKALIN, S. V. Lermontov. Znakomyas s biografiei poeta... [Lermontov. Getting to know the poet's biography]. Moscow: Znanie, 1991.

GERASIMENKO, A. Syn stradanya [The son of suffering]. Moscow: Izd-vo Tri L, 2002.

KORNILOV, O. A. Yazykovye kartiny mira kak proizvodnye natsionalnykh mentalitetov: Uchebnoe posobie [Language-based worldviews as a product of national mentalities: A manual]. Moscow: KDU, 2011.

KULIBINA, N. V. Zachem, chto i kak chitat? [What for, what and how should one read?]. Moscow: Zlatoust, 2001.

LERMONTOV, M. Y. Geroi nashego vremeni. Roman [A Hero of Our Time. A novel]. Moscow. Prosveshchenie, 1998. 138 p.

LIPICH, V. V. A.S. Lermontov: dve grani russkogo romantizma. Belgorod: Izd-vo Belgu, 2005.

LYSAKOVA, I. P. Metodika obucheniya russkomu yazyku kak inostrannomu: uchebnoe posobie dlya vuzov [The methods of teaching Russian as a foreign language: A manual for universities]. Moscow: Russkii yazyk, 2016.

MATVEEV, A. R. Prakticheskie trudnosti pri ispolzovanii tekstov russkoi khudozhestvennoi literatury na zanyatiyakh po RKI [Practical difficulties in using Russian fiction during classes of Russian as a foreign language]. In: Russkaya literatura v inostrannoi auditorii [Russian literature in a foreign audience]. St. Petersburg: Russian State Pedagogical University named after A.I. Herzen, 2019. p. 208-214. 
PETROVA, S. M. Innovatsionnaya metodika: literatura, semiotika, grafika v sisteme obucheniya russkomu yazyku kak inostrannomu: uchebnoe posobie [Innovational methods: literature, semiotics, graphics in the system of teaching Russian as a foreign language. A manual]. Yakutsk: Izdatelskii dom SVFU, 2020.

RANDZHANA, B. Prepodavanie russkoi literatury v inostrannoi (indiiskoi) auditorii [Teaching Russian literature to a foreign (Indian) audience]. In: MELNIKOVA, T. N. (Ed.). BelarusIndiya-Rossiya: sotrudnichestvo v oblasti prepodavaniya russkogo yazyka kak inostrannogo [Belarus, India, Russia: cooperation in teaching Russian as a foreign language]. Minsk: Belarusian State Medical University; OOO "Nauchnyy mir", 2019. p. 197-200.

\section{RUSSIA. Kontseptsiya prepodavaniya russkogo yazyka i literatury v} obshcheobrazovatelnykh organizatsiyakh Rossiiskoi Federatsii [The concept of teaching Russian language and literature in general education institutions of the Russian Federation]. State Russian Language Institute named after A.S. Pushkin, 2016. Available:

http://www.pushkin.institute/projects/gosconcept/conc-dox/Concept_project_final.pdf. Access: 10 Jul. 2020.

\section{SCHUKIN, A. N. Sovremennye intensivnye metody i tekhnologii obucheniya inostrannym} yazykam: Uchebnoe posobie [Modern intensive methods and technologies in teaching foreign languages: A manual]. Moscow: Filomatis. 2010.

SMOL, E. A. Sposoby verbalizatsii kontsepta "lyubov" v romane "Geroi nashego vremeni" M.Y. Lermontova [Ways of verbalising the concept of love in the novel "A Hero of Our Time" by M.Y. Lermontov]. In: Universitetskie chteniya - 2015, 13-14 yanvarya. Metodicheskie materialy PGLU [University Readings 2015, Jan. 13-14. Methodical materials of Pyatigorsk State Linguistic University (PGLU)]. Pyatigorsk: Izd-vo PGLU, 2015.

VISHNYAKOV, S. A. Russkii yazyk kak inostrannyi: Uchebnik [Russian as a foreign language: A manual]. Moscow: Flinta: Nauka, 2013. 240 p.

ZHURAVLEVA, A. S. Primenenie tekstov khudozhestvennoi literatury na zanyatiyakh russkogo yazyka kak inostrannogo. In: PRISCHEPA, I. M. (Ed.). Nauka - obrazovaniyu, proizvodstvu, ekonomike. Materialy XXIII (70) Regionalnoi nauchno-prakticheskoi konferentsii prepodavatelei, nauchnykh sotrudnikov i aspirantov. Vitebsk: Vitebsk State University named after P.M. Masherov, 2018. 


\section{How to reference this article}

PETROVA, S. M. Understanding the nature of the main character in russian literature on the material of the novel "A hero of our time" by M. Y. Lermontov. Rev. EntreLínguas, Araraquara, v. 7, n. esp. 2, e021019, 2021. e-ISSN: 2447-3529. DOI: https://doi.org/10.29051/el.v7iesp.2.15145

Submitted: 05/01/2021

Required revisions: $26 / 02 / 2021$

Approved: $24 / 03 / 2021$

Published: 01/06/2021 